\title{
Comparative Study of Tensile Strength Ratio of Asphalt Concrete Mixed with AC 60-70 and Polymer Modified Asphalt
}

\author{
Panatda Kasikitwiwat ${ }^{\mathrm{a}}$, Siranya Thongchart ${ }^{\mathrm{b}}$, Somchai Prayongphan ${ }^{\mathrm{c}}$, \\ and Krissana Jantarachot ${ }^{\mathrm{d}, *}$ \\ Department of Civil Engineering, Faculty of Engineering at Kamphaeng Saen, Kasetsart University, \\ Nakhon Pathom 73140, Thailand \\ E-mail: afengpak@ku.ac.th, bfengsytc@ku.ac.th, cfengscpp@ku.ac.th, \\ d,*fengknj@ku.ac.th (Corresponding author)
}

\begin{abstract}
In Thailand, the temperature can reach $44.6{ }^{\circ} \mathrm{C}$ with the lowest temperature of $-1.4^{\circ} \mathrm{C}$ recorded in northeastern Thailand. When the air temperature changes, the state temperature of asphalt concrete also changes. To ensure a longer usage life of the surface of asphalt concrete and better durability of the asphalt concrete surface in the range of Thai environmental conditions, this research used the tensile strength ratio method to compare the damage caused by moisture. Samples $(5 \%$ and $7 \%$ air voids of the volume of the asphalt concrete) were compared for a control group and a conditioned group, which simulated field behavior occurring in Thailand. It was discovered that the resistance to damage caused by moisture depended on the size of the mixed aggregate material and the amount of asphalt cement present in the mixture. The sample containing mixed sizes according to the lower limit had a higher tensile strength than the mixed sizes according to the upper limit and the air voids of asphalt concrete were inversely proportional to its resistance to moisture damage. As the air void volume increased, the tensile strength ratio decreased.
\end{abstract}

Keywords: Limestone, AC 60-70, PMA, indirect tensile strength, tensile strength ratio.

ENGINEERING JOURNAL Volume 25 Issue 10

Received 22 March 2021

Accepted 5 October 2021

Published 31 October 2021

Online at https:/ / engj.org/

DOI:10.4186/ej.2021.25.10.51 


\section{Introduction}

In Thailand, the main method of transportation and commuting is via the road network. Asphalt concrete is the main form of construction $(94.69 \%)$ for most of the nation's road surfaces $(94,580 \mathrm{~km})$ that are under the supervision of the Department of Thai Highways and Department of Rural Roads. [1]

The most northern point in Thailand is located in Mae Sai district, Chiang Rai province at $20^{\circ} 28^{\prime} \mathrm{N} 99^{\circ} 57^{\prime}$ $\mathrm{E}$ and the most southern point is located in Betong district, Yala province at $5^{\circ} 37^{\prime} \mathrm{N} 101^{\circ} 8^{\prime} \mathrm{E}$ [2]; there is a wide range in temperatures between these two locations, where temperatures have reached $44.6{ }^{\circ} \mathrm{C}[3]$ and dropped as low as $-1.4^{\circ} \mathrm{C}$ [4] with subsequent direct effects on the asphalt concrete surface.

Moisture damage in asphalt concrete road surfaces in use was first recognized at the beginning of 1930 with many studies conducted since then [5]. From 1960 onward, problems regarding moisture damage of asphalt concrete became the focus [6]. Although there have been developments regarding the mixing of asphalt concrete and designing the mixture ratio, moisture damage remains one of the most complicated problems for asphalt concrete surfaces [7]. The damage caused by moisture in asphalt concrete results in the loss of strength and durability of the asphalt concrete mixture [8-11].

Asphalt concrete surfaces are sensitive to the permeation of water which results in decreased adhesion between the asphalt cement and the aggregates that results in subsequent damage to the surfaces [12]. The loss of adhesion is one of the main causes of decreased durability in the physical properties of hot-mixed asphalt concrete [13]. This process may cause problems, especially in areas where water is present as the early surface damage arises from the effect of water permeation which destroys the adhesion and thereafter causes cracks which then will increase the severity of damage such as rutting, raveling, shoving and bleeding $[6,14,15]$.

Moisture damage due to water permeation presents a problem as the main responsible department has found that road surface maintenance works become highly complicated when this problem occurs. Many factors contribute to an increase in the cost of maintenance and recovery of asphalt concrete road surfaces $[7,16]$.

Control of the moisture sensitivity of asphalt concrete can be separated into two categories: 1) the properties and sources of the asphalt concrete (the asphalt cement and the aggregates); and 2) water drainage, climate, the environment and road traffic volume [17-19].

Some researchers have reported that the moisture damage in asphalt concrete can be avoided by preventing water from permeating into the concrete or by improving the strength of asphalt concrete adhesion [20-22]. However, the complications which resulted from moisture damage are difficult to test and analyze and therefore behavioral simulation has been conducted to predict moisture damage [23]. There are many ways to speed up the results of water permeation in laboratories such as by freezing and poaching of hot-mixed asphalt concrete which has been saturated by vacuuming inside the asphalt concrete [24] and conducting experiments to determine the tensile strength ratio (TSR) which can then be used to calculate the remaining strength of asphalt concrete samples by applying indirect tensile forces after simulating moisture damage conditions [25].

In the current behavioral simulation research carried out in Thailand, two types of asphalt concrete mixes were designed using mixed proportions of aggregate materials (limestone) and two types of asphalt cement. The moisture damage was compared based on the TSR method. The two samples of asphalt concrete were prepared at $5 \%$ and $7 \%$ air voids of the volume of the asphalt concrete to demonstrate the impact on the tensile strength of the asphalt concrete. In each set, a comparison was made between two groups, namely, the control group and the conditioned group.

\section{Materials and Methods}

\subsection{Materials}

Asphalt concrete is a construction layer consisting of a mixture of asphalt and continuously graded aggregate, mixed, spread and compacted at a specific temperature [26]. the Superpave system is used to design the asphalt concrete. It is essential to determine the target values for compaction and the maximum theoretical specific gravity $\left(G_{m m}\right)$ is a critical hot mix asphalt (HMA) characteristic because it is used to calculate the percentage of air voids in compacted HMA [27]. Figure 1 provides a flow chart with the raw materials consisting of aggregates, which are limestone, at 2 mixed sizes (according to their upper and lower limits) and 2 types of asphalt cement (AC 60/70 and PMA).

\subsubsection{Aggregate}

The testing of the physical properties of the aggregates used in this research was done following the requirements of the Superpave system and the regulations of the Thailand Department of Highways, as shown in Table 1. The aggregate material used was limestone that is commonly used in pavement construction in Thailand and its physical characteristics are shown in Fig. 2. The researcher determined the proportions of the mixtures close to the asphalt concrete pavement standard requirements of the Thailand Department of Highways. They were divided into 2 types (upper limit and lower limit) and assorted sizes, as shown in Table 2, with the particle distribution characteristics of the aggregate material shown in Fig. 4. The restricted zone resides along the maximum density gradation between the intermediate size $(2.36 \mathrm{~mm})$ and the $0.3 \mathrm{~mm}$ size. The gradation in the restricted zone indicates a mixture that possesses too much fine sand in relation to total sand, which practically affects the asphalt mixture making it difficult to compact during construction and results in reduced resistance to permanent deformation. 


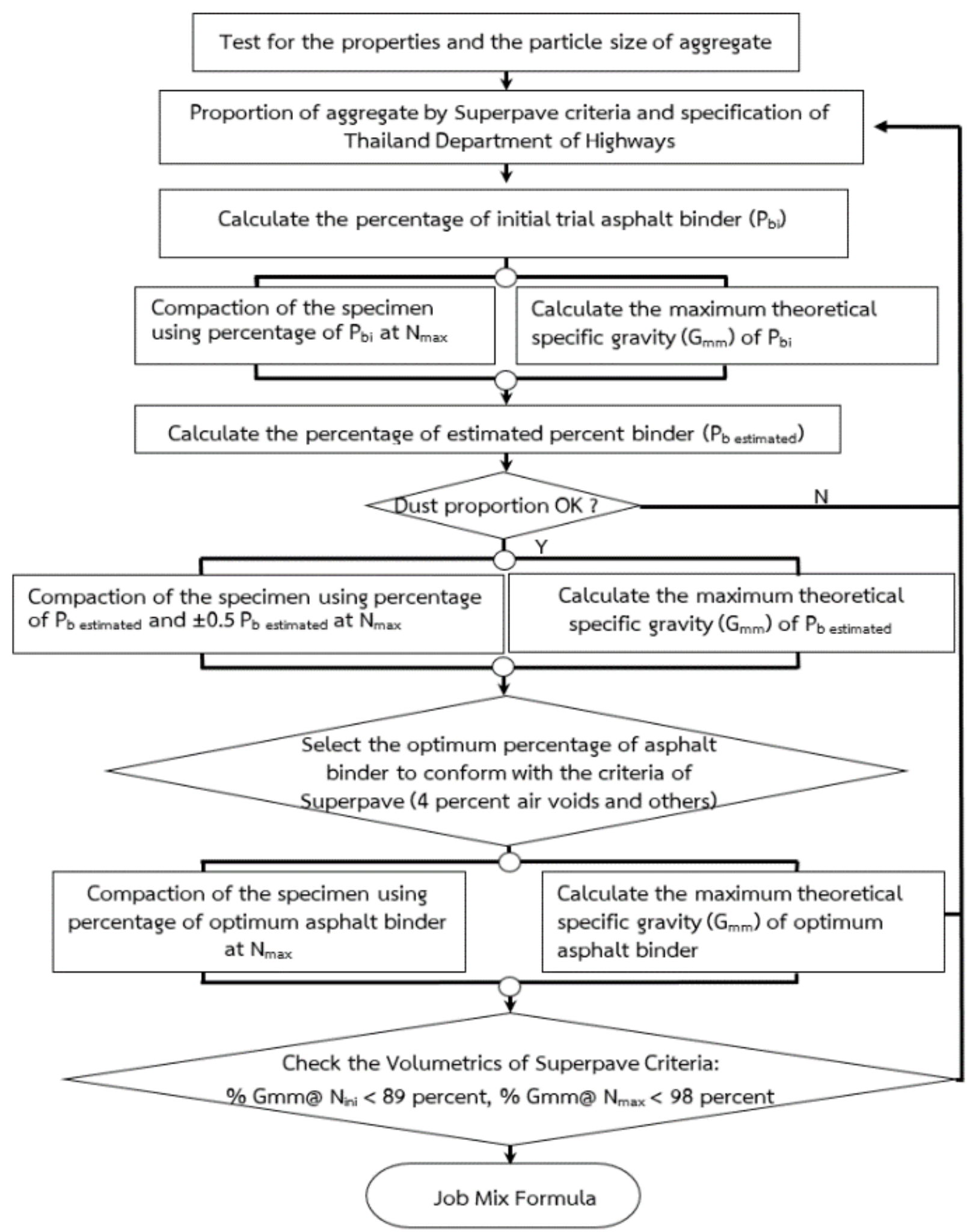

Fig. 1. Mixture flow chart for Superpave method [28]. 


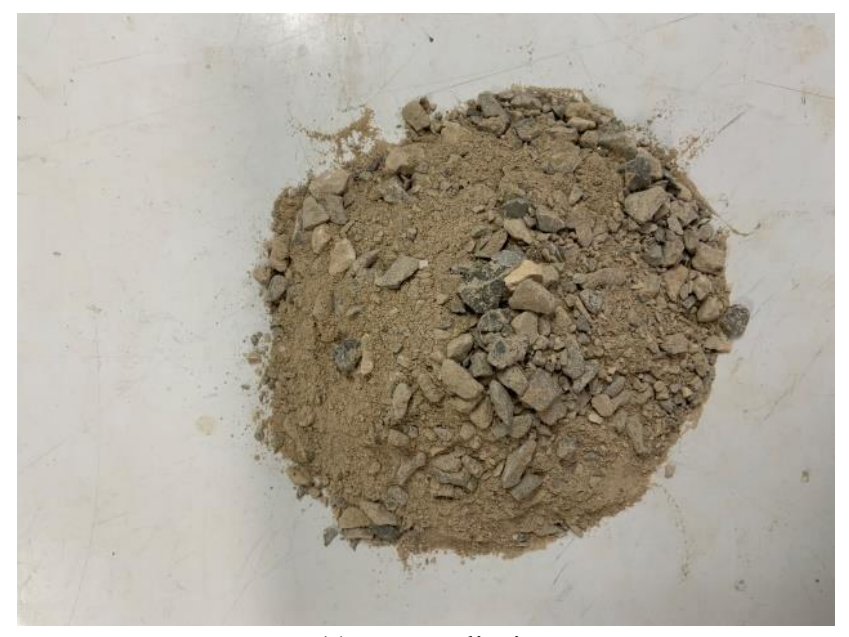

(a) Upper limit

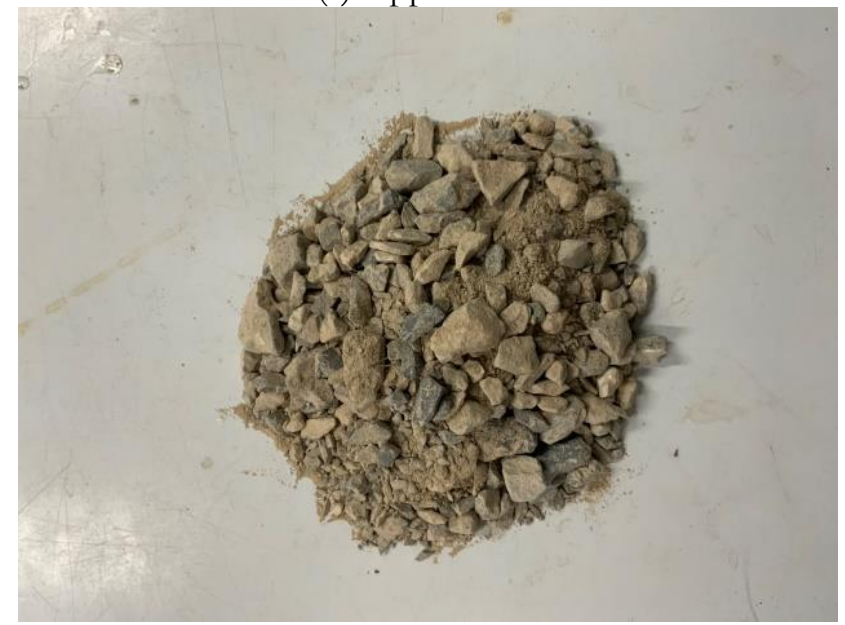

(b) Lower limit

Fig. 2. Aggregate materials used in the research.

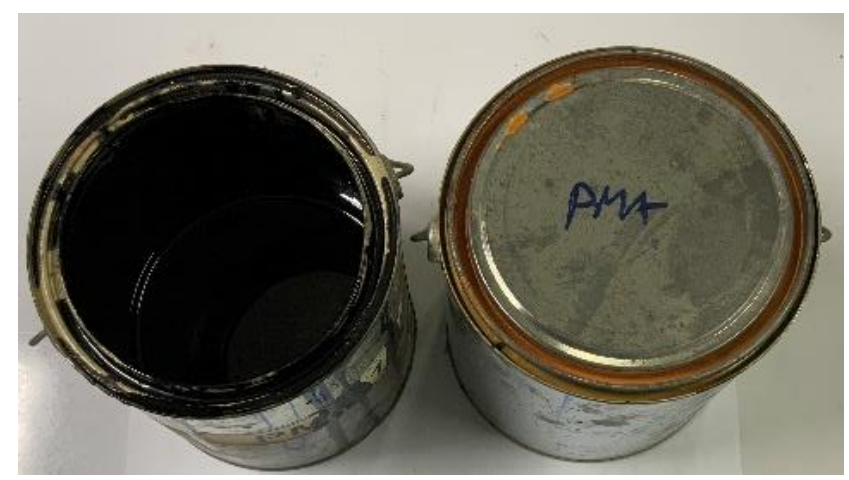

(a) PMA

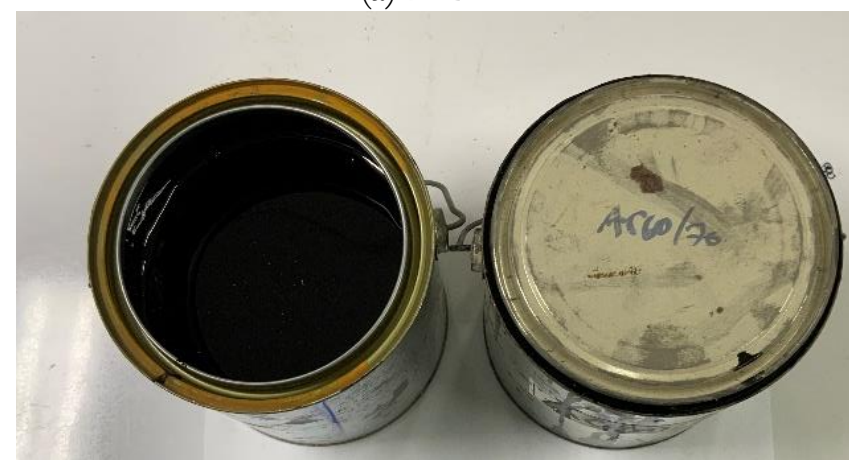

(b) AC 60-70
Table 1. Coarse and fine aggregate properties [29].

\begin{tabular}{|c|c|c|c|c|c|c|c|c|}
\hline \multirow[b]{2}{*}{ Property } & \multicolumn{3}{|c|}{ Bin 1} & \multirow[b]{2}{*}{$\operatorname{Bin} 2$} & \multirow[b]{2}{*}{ Bin 3} & \multirow[b]{2}{*}{ Total } & \multirow[b]{2}{*}{ Criteria } & \multirow{2}{*}{$\begin{array}{l}\text { Test } \\
\text { method }\end{array}$} \\
\hline & $\begin{array}{l}\text { Pass } \\
\# 200\end{array}$ & $\begin{array}{l}\text { Retain } \\
\# 200\end{array}$ & Totall & & & & & \\
\hline $\begin{array}{l}\text { Apparent } \\
\text { specific } \\
\text { gravity, (GA) }\end{array}$ & 2.769 & 2.745 & 2.749 & 2.746 & 2.733 & 2.743 & - & $\begin{array}{l}\text { ASTM } \\
\text { C } 127, \\
128\end{array}$ \\
\hline $\begin{array}{l}\text { Bulk specific } \\
\text { gravity, }(\mathrm{GB})\end{array}$ & - & 2.719 & 2.728 & 2.703 & 2.684 & 2.707 & - & \\
\hline Absorption, (\%) & - & 0.74 & - & 0.58 & 0.57 & & - & \\
\hline $\begin{array}{l}\text { Uncompacted } \\
\text { void content } \\
\text { of fine } \\
\text { aggregate, }(\%)\end{array}$ & & & 45.9 & & & & $>45$ & $\begin{array}{l}\text { AASHTO } \\
\text { TP } 33\end{array}$ \\
\hline $\begin{array}{l}\text { Sand equivalent, } \\
(\%)\end{array}$ & & & 73.0 & & & & $>50$ & $\begin{array}{l}\text { ASTM } \\
\text { D } 2419\end{array}$ \\
\hline $\begin{array}{l}\text { Flakiness } \\
\text { index, }(\%)\end{array}$ & & & & & 25 & & $<30$ & BS 812 \\
\hline $\begin{array}{l}\text { Elongation } \\
\text { index, }(\%)\end{array}$ & & & & & 18 & & $<30$ & BS 812 \\
\hline $\begin{array}{l}\text { Los Angeles } \\
\text { abrasion, (\%) }\end{array}$ & & & & & 32.55 & & $<40$ & $\begin{array}{l}\text { ASTM } \\
\text { C } 131\end{array}$ \\
\hline $\begin{array}{l}\text { Percentage of } \\
\text { crushed } \\
\text { fragments in } \\
\text { gravel, }(\%)\end{array}$ & & & & 100 & 100 & & $>90$ & \\
\hline $\begin{array}{l}\text { Soundness test } \\
\text { of aggregate } \\
\text { (Solution of } \\
\text { sodium } \\
\text { sulfate), }(\%)\end{array}$ & $\begin{array}{l}\text { Fine a } \\
\text { Coars }\end{array}$ & $\begin{array}{l}\text { gregate } \\
\text { aggregate }\end{array}$ & $\begin{aligned} & =2.90 \\
e & =0.47\end{aligned}$ & & & & $\begin{array}{l}<9 \\
<9\end{array}$ & $\begin{array}{l}\text { ASTM } \\
\text { C } 88\end{array}$ \\
\hline $\begin{array}{l}\text { Flat of } \\
\text { elongated } \\
\text { particles in } \\
\text { coarse } \\
\text { aggregate, }(\%)\end{array}$ & & & & 8 & 3 & & $<10$ & $\begin{array}{l}\text { ASTM } \\
\text { D } 479\end{array}$ \\
\hline $\begin{array}{l}\text { Absorption of } \\
\text { asphalt, }(\%)\end{array}$ & $\mathrm{AC}$ & $0-70=0.2$ & 236 & PMA & $=0.237$ & & & $\begin{array}{l}\text { ASTM } \\
\text { D } 2041\end{array}$ \\
\hline
\end{tabular}

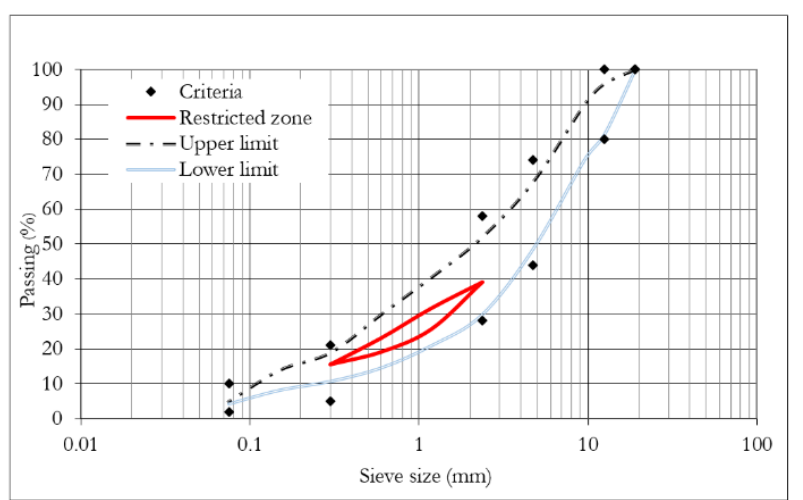

Fig. 4. Aggregate particle size distribution for limestone [29].

\subsubsection{Asphalt cement}

The two types of asphalt cement used in this research were AC 60-70 which is widely used in Thailand and polymer-modified asphalt (PMA) which can enhance the behavior of the properties of the mixture $[30,31]$. The test results of the physical properties of the asphalt cement are shown in Table 3 and the results of the physical characteristics are shown in Fig. 3.

Fig. 3. Asphalt cement used in the research. 
Table 2. Gradation for limestone blend.

\begin{tabular}{|c|c|c|c|c|c|}
\hline \multirow{2}{*}{\multicolumn{2}{|c|}{ Sieve size }} & \multicolumn{2}{|c|}{ Passing } & \multirow{3}{*}{$\begin{array}{c}\text { Criteria } \\
(\%)\end{array}$} & \multirow{3}{*}{$\begin{array}{c}\begin{array}{c}\text { Restricted } \\
\text { zone }\end{array} \\
(\%)\end{array}$} \\
\hline & & \multirow{2}{*}{$\begin{array}{c}\text { Lower } \\
\text { limit } \\
(\%)\end{array}$} & \multirow{2}{*}{$\begin{array}{c}\text { Upper } \\
\text { limit } \\
(\%)\end{array}$} & & \\
\hline Number & $(\mathrm{mm})$ & & & & \\
\hline $3 / 4^{\prime \prime}$ & 19 & 100 & 100 & 100 & - \\
\hline $1 / 2^{\prime \prime}$ & 12.5 & 81.54 & 96.00 & $80-100$ & - \\
\hline $3 / 8^{\prime \prime}$ & 9.5 & 74.13 & 90.00 & - & - \\
\hline$\# 4$ & 4.75 & 48.83 & 68.00 & $44-74$ & - \\
\hline$\# 8$ & 2.36 & 29.86 & 52.00 & $28-58$ & 39.1 \\
\hline \#16 & 1.18 & 20.98 & 40.50 & - & $25.6-31.6$ \\
\hline \#30 & 0.6 & 14.67 & 30.00 & - & $19.1-23.1$ \\
\hline$\# 50$ & 0.3 & 10.77 & 19.00 & $5-21$ & 15.5 \\
\hline \#100 & 0.15 & 8.25 & 14.00 & - & - \\
\hline \#200 & 0.075 & 4.31 & 5.00 & $2-10$ & - \\
\hline
\end{tabular}

Table 3. Physical properties of asphalt binder [28].

\begin{tabular}{|c|c|c|c|}
\hline \multirow[b]{2}{*}{ Property } & \multicolumn{2}{|c|}{ Binder } & \multirow{2}{*}{$\begin{array}{c}\text { Test } \\
\text { method }\end{array}$} \\
\hline & $\begin{array}{l}\text { AC } 60 / 70 \\
\text { (Criteria) }\end{array}$ & $\begin{array}{c}\text { PMA } \\
\text { (Criteria) }\end{array}$ & \\
\hline $\begin{array}{l}\text { Specific gravity } \\
\left(25^{\circ} \mathrm{C}\right)\end{array}$ & $1.02(-)$ & $1.02(-)$ & $\begin{array}{c}\text { ASTM D } \\
70\end{array}$ \\
\hline $\begin{array}{l}\text { Penetration test } \\
\left(25^{\circ} \mathrm{C}\right),(0.1 \\
\mathrm{mm})\end{array}$ & $67(60-70)$ & $61(60-70)$ & $\underset{5}{\operatorname{ASTM} \mathrm{D}}$ \\
\hline $\begin{array}{l}\text { Softening point, } \\
\left({ }^{\circ} \mathrm{C}\right)\end{array}$ & $46.2(>46)$ & $71.1(>70)$ & $\begin{array}{c}\text { ASTM D } \\
36\end{array}$ \\
\hline Viscosity & 394 & 1220 & ASTM D \\
\hline $\begin{array}{l}\left(135^{\circ} \mathrm{C}, 20 \mathrm{rpm},\right. \\
\text { spindle } 21),(\mathrm{cP})\end{array}$ & $(-)$ & $(1100)$ & 4402 \\
\hline $\begin{array}{l}\text { Ductility }\left(25^{\circ} \mathrm{C}\right) \text {, } \\
(\mathrm{cm})\end{array}$ & $>100$ & $>100$ & $\begin{array}{c}\text { ASTM D } \\
113 \\
\end{array}$ \\
\hline
\end{tabular}

\subsection{Method}

\subsubsection{Design process using Superpave method}

The process design method consisted of: 1) testing the physical properties of the aggregate material to determine the appropriate proportions of the size of the material so the total mass meet the requirements of the Superpave criteria and the specifications of the Thailand Department of Highways; 2) calculating the percentage of initial trial asphalt binder $\left(\mathrm{P}_{\mathrm{bi}}\right)$ based on the specific gravity of the material and a nominal maximum size; 3) compacting the sample cubes using the Superpave gyratory compactor (SGC) by applying a constant pressure of $600 \mathrm{kPa}$ to the base of the rotating machine at a constant cycle speed of 30 rounds per minute, with the position of the compaction sample at an angle of 1.25 degrees. The machine is shown in Fig. 5 and the $\mathrm{P}_{\mathrm{bi}}$ was determined by compaction at the maximum number of gyrations $\left(\mathrm{N}_{\max }\right)$ of three samples. The number of compaction cycles depends on the traffic volume and the average high air temperature as well as finding the maximum theoretical specific gravity $\left(G_{m m}\right)$ at $\mathrm{P}_{\mathrm{bi}}$; 4) calculating the percentage of asphalt, the suitable estimated percent binder $\left(\mathrm{P}_{\mathrm{b}}\right.$ estimated $)$ with the dust proportion between 0.6 and $1.2 ; 5$ ) compacting the sample cubes using $\mathrm{P}_{\mathrm{b}}$ estimated and \pm 0.5 percent at $\mathrm{N}_{\max }$, and selecting the appropriate estimated percent binder $\left(\mathrm{P}_{\mathrm{b}}\right.$ estimated') according to the Superpave criteria (4\% air voids $\left(V_{a}\right)$ and others); 6) compacting the sample cubes using the percentage of actual asphalt cement at $\mathrm{N}_{\max }$ and checking the volumetric properties according to the Superpave criteria $\% \mathrm{G}_{\mathrm{mm}} @ \mathrm{~N}_{\text {initial }}<89 \%, \% \mathrm{G}_{\mathrm{mm}}$ @ $\mathrm{N}_{\text {maximum }}$ $<98 \%$ ) for voids in the mineral aggregate (VMA) and voids filled with asphalt (VFA) at the designed number of gyrations $\left(\mathrm{N}_{\mathrm{des}}\right)$ and the density of the mixture at the initial number of gyrations $\left(\mathrm{N}_{\text {ini }}\right)$ and $\left.\mathrm{N}_{\max } ; 7\right)$ compounding the mixture using an SGC. In Thailand the temperature used for mixing is $160{ }^{\circ} \mathrm{C}$ for AC $60-70$ and $180^{\circ} \mathrm{C}$ for PMA. Afterward, the mixer temperature (for both $\mathrm{AC}$ 60-70 and PMA binder) was $165-170{ }^{\circ} \mathrm{C}$; 8) placing the asphalt concrete sample into the SGC, setting the number of compactions at 9 gyrations for $\mathrm{N}_{\text {ini }}, 135$ gyrations for $\mathrm{N}_{\text {des }}$ and 220 gyrations for $\mathrm{N}_{\max }$. During compaction, the height was measured after each gyration and the number of gyrations was also recorded. The average design was based on a high air temperature of $44^{\circ} \mathrm{C}$ and 10-30 million cycles of an equivalent single axle load (ESAL); and 9) finding the specific gravity and calculating the air voids in the sample.

The design criteria for the mixture using the Superpave method were that the VMA was greater than $14 \%$, the VFA was in the range $65-75 \%$, and the $V_{a}$ was $4 \%$ in the compressed mixture at the designed number of cycles, as shown in Fig. 1. Thus, the appropriate amount of asphalt cement was obtained.

\subsubsection{Asphalt concrete samples}

The sample cubes were prepared using the SGC with the appropriate amounts of asphalt cement according to Fig. 1. In determining the appropriate asphalt cement content, the $\mathrm{V}_{\mathrm{a}}$ volume required was approximately $4 \%$ by volume of the asphalt concrete. The samples of asphalt concrete used in the research were divided into four types:

1) PMA Upper = asphalt concrete mixed with PMA binder and upper limit limestone aggregate; 2) PMA Lower $=$ asphalt concrete mixed with PMA binder and lower limit limestone aggregate; 3) AC 60-70 Upper = asphalt concrete mixed with AC 60-70 binder and upper limit limestone aggregate; and 4) AC 60-70 Lower = asphalt concrete mixed with AC 60-70 binder and lower limit limestone aggregate.

All four types of asphalt concrete samples were prepared using the appropriate amounts of asphalt cement obtained from the design to be compacted to achieve 2 sets of air void values of $5 \%$ and $7 \%$. 


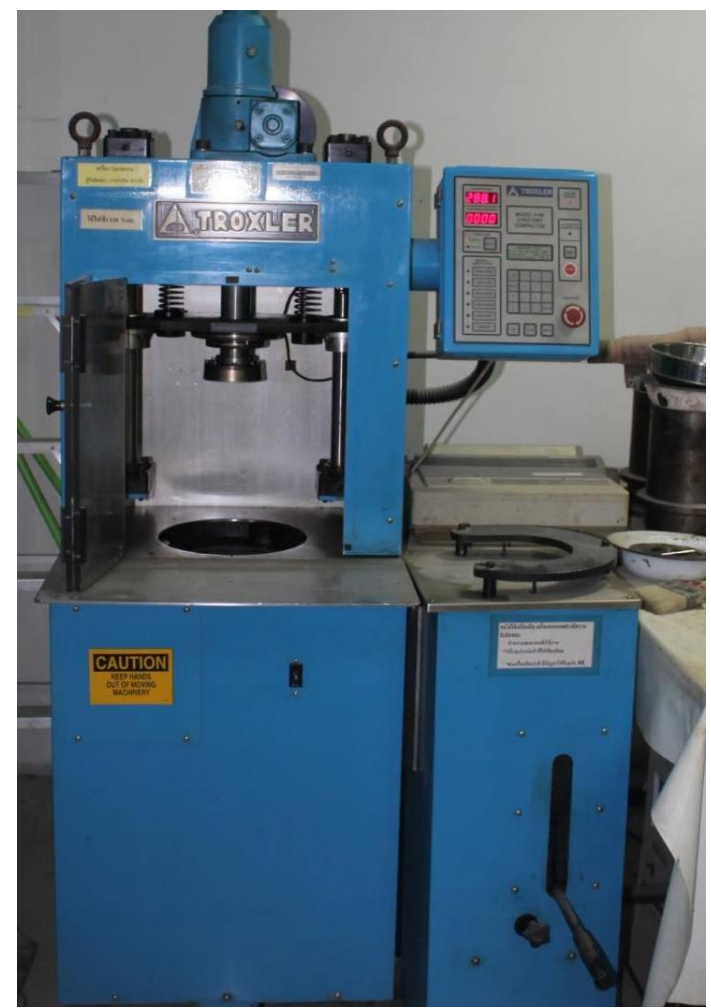

Fig. 5. Photo of Superpave gyratory compactor.

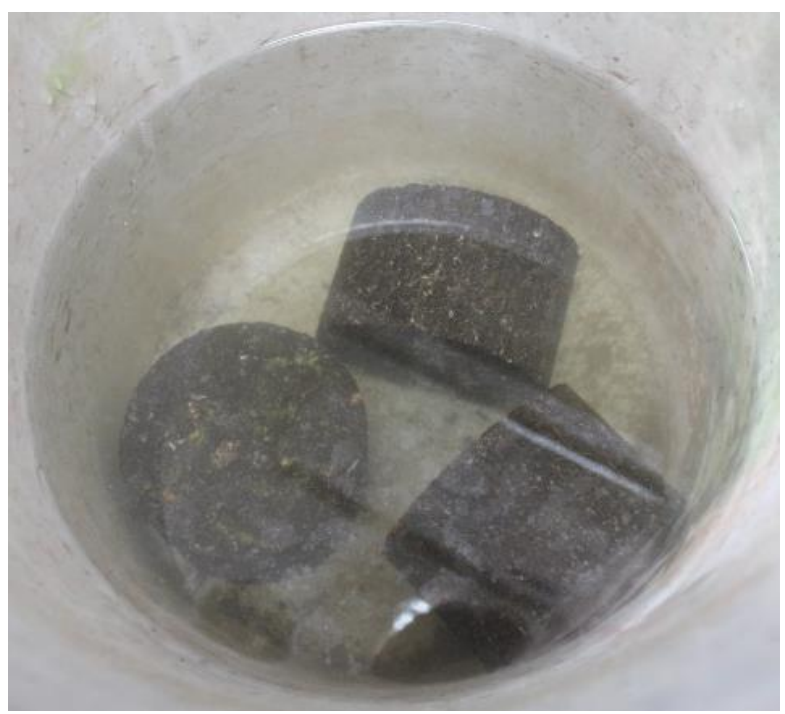

(a) Samples immersed in water at $25{ }^{\circ} \mathrm{C}$.

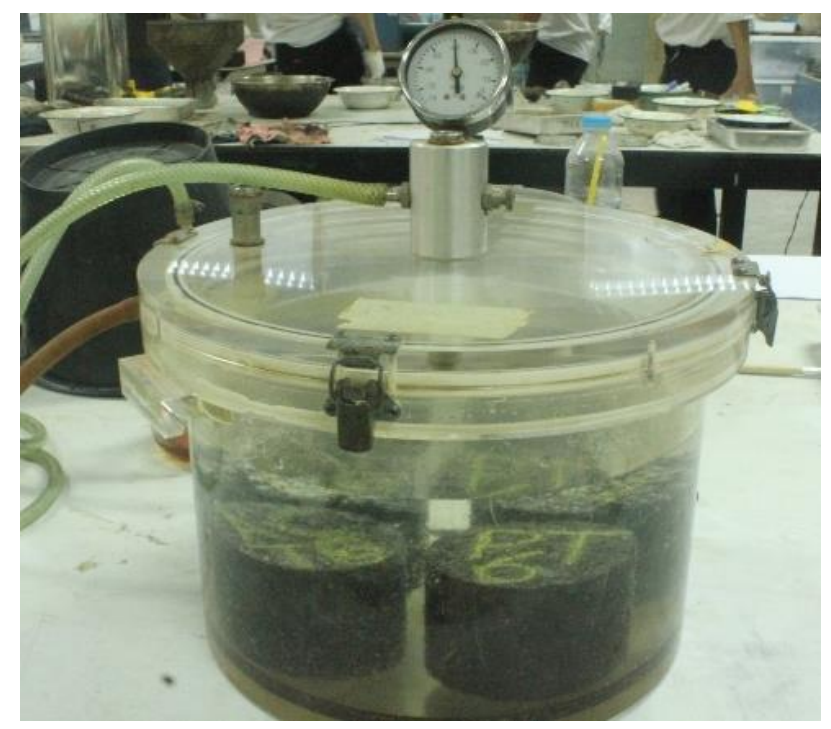

(b) Vacuum removal of air in samples in water.

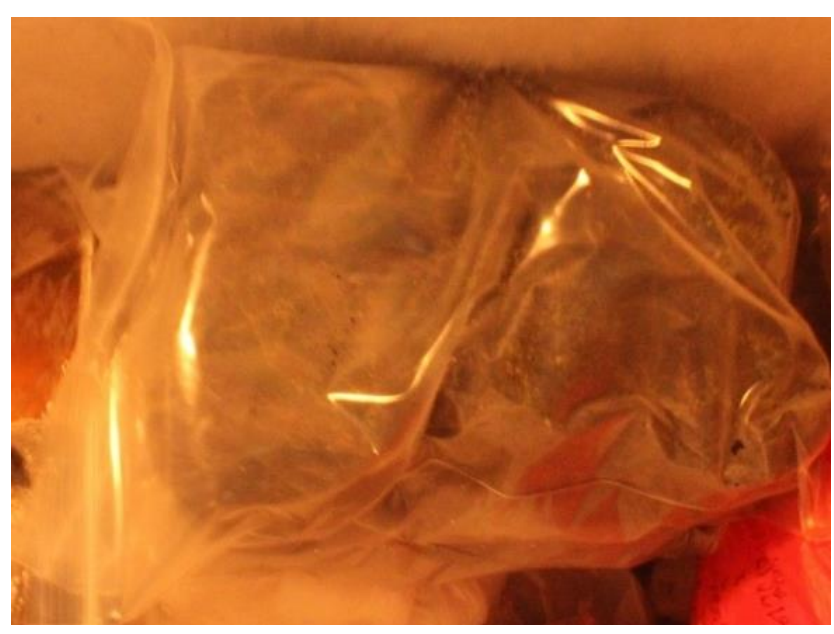

(c) Freezing samples at $-15^{\circ} \mathrm{C}$.

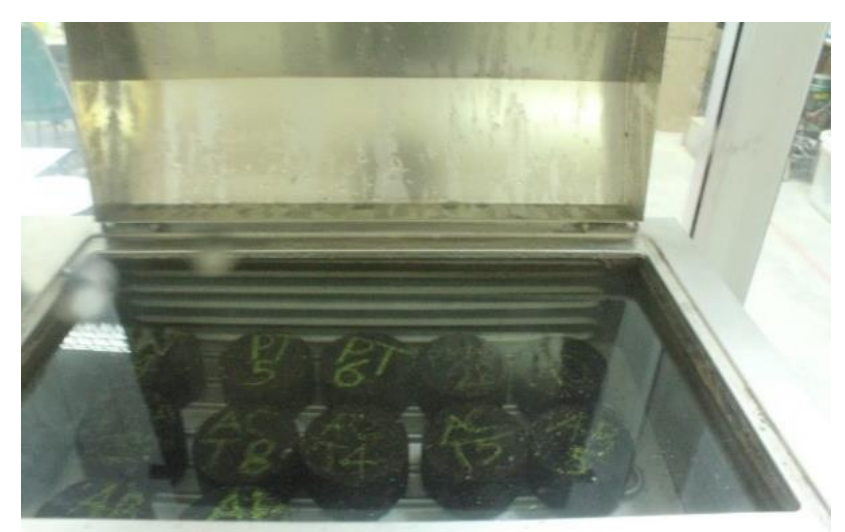

(d) Samples immersed in water at $60{ }^{\circ} \mathrm{C}$.

Fig. 6. Experimental steps to compare two groups.

For each set, the comparisons were between 1) the control group, achieved by incubating the sample cubes in water at $25^{\circ} \mathrm{C}$ for 2 hours, as shown in Fig. 6(a); and 2) the condition group, achieved by vacuuming the air of the sample cubes in the water at a pressure of $45 \mathrm{~cm} \mathrm{Hg}$ for 5-10 minutes, as shown in Fig. 6(b). The samples had 70- 
$80 \%$ water saturation, and thereafter the samples were frozen to simulate the lowest recorded temperature in Thailand $\left(-1.4^{\circ} \mathrm{C}\right)$. The samples were frozen by reducing the temperature down to $-15{ }^{\circ} \mathrm{C}$ to create a more severe condition than that of the lowest recorded temperature point in Thailand for 16 hours, as shown in Fig. 6(c), followed by the samples being immersed in water to simulate the highest recorded temperature in Thailand $\left(44.6^{\circ} \mathrm{C}\right)$, by increasing the temperature up to $60^{\circ} \mathrm{C}$ to create a more severe condition for 24 hours, as shown in Fig. 6(d). Then, the samples were left immersed in water at $25{ }^{\circ} \mathrm{C}$ for 2 hours (the same condition as for the control group), as shown in Fig. 6(a).

\subsubsection{Comparison of TSR using indirect tensile strength (ITS) methods}

After the asphalt concrete block samples had been immersed in water at $25^{\circ} \mathrm{C}$ for 2 hours, both sample groups were tested for their engineering properties using the ITS test to determine the strength of the asphalt concrete material by applying compression loading which could be either a static load or a repression load depending on the case. The compression load was applied through a bar $13 \mathrm{~mm}$ wide where the bar surface was in contact with the sample mass at an arc radius equal to the sample radius to enable the even distribution of pressure and to maintain a constant pressure area, thus creating uniform tensile stress. The ITS test compared the TSR between the conditioned group and the control group. Figure 7 shows the installation of the sample mass in the ITS test device.
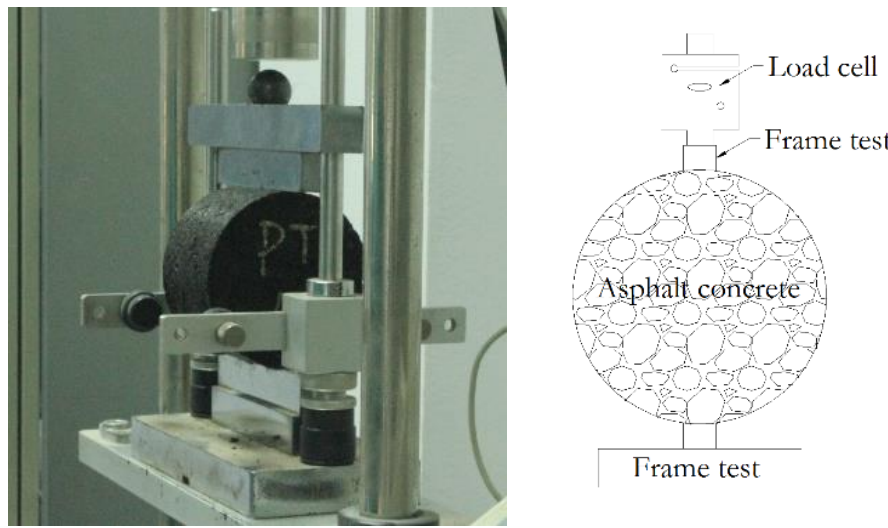

Fig. 7. Installation characteristics of sample for indirect tensile test.

\section{Results and Discussion}

The appropriate estimate assessment of $\mathrm{P}_{\mathrm{b}}$ estimated was obtained for the upper limit gradation limestone was $4.54 \%$ and the optimum amount of $\mathrm{P}_{\mathrm{b}}$ estimated' for the lower limit gradation limestone was $4.75 \%$, as shown in Table 4. The VMA was not less than $14 \%$ and the VFA was within $65-75 \%$ of the upper limit gradation that was less than the lower limit gradation. As a result, the $\mathrm{P}_{\mathrm{b}}$ estimated of the asphalt concrete mixture of the upper limit gradation was less than that of the lower limit gradation, and the asphalt concrete sample had a $\mathrm{V}_{a}$ value of approximately $4 \%$, which was following the Superpave method. When the suitable asphalt cement content was obtained, it was ground using the SGC to obtain samples with air voids of $5 \%$ and $7 \%$ of the volume of asphalt concrete and the TSR was compared using the ITS test results. The outputs obtained are shown in Tables 5 and, 6.

Table 4. Results for asphalt binder mixture [29].

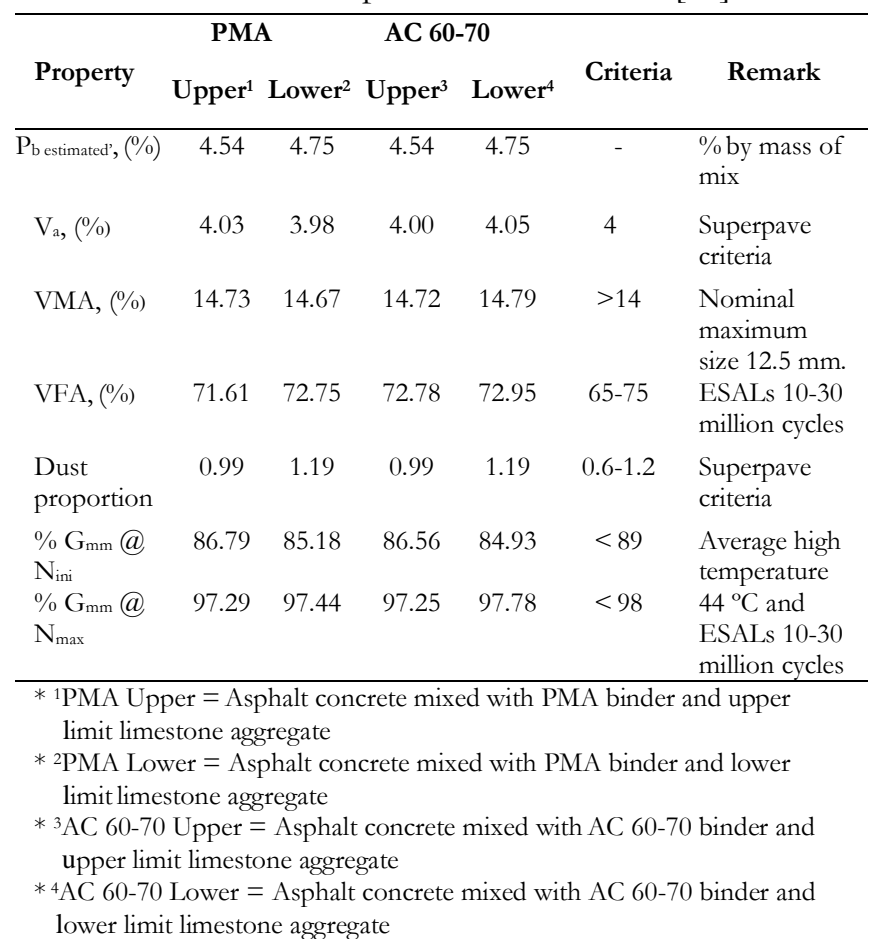

Table 5. Results of TSR test at $5 \%$ air voids.

\begin{tabular}{|c|c|c|c|c|c|c|c|c|}
\hline \multirow{2}{*}{$\begin{array}{c}\text { Type } \\
\text { Group }\end{array}$} & \multicolumn{2}{|c|}{ PMA } & \multicolumn{2}{|c|}{$\begin{array}{c}\text { PMA } \\
\text { LOWER }\end{array}$} & \multicolumn{2}{|c|}{$\begin{array}{c}\text { AC 60/70 } \\
\text { UPPER }\end{array}$} & \multicolumn{2}{|c|}{$\begin{array}{l}\text { AC 60-70 } \\
\text { LOWER }\end{array}$} \\
\hline & $1 *$ & $2 *$ & $1 *$ & $2 *$ & $1 *$ & $2^{*}$ & $1^{*}$ & $2 *$ \\
\hline $\begin{array}{l}\text { Air voids, } \\
(\%)\end{array}$ & 5.07 & 5.00 & 5.03 & 5.02 & 5.05 & 5.17 & 4.95 & 5.01 \\
\hline $\begin{array}{l}\text { Volume } \\
\text { air voids, } \\
\left(\mathrm{cm}^{3}\right)\end{array}$ & 26.56 & 26.19 & 26.54 & 26.77 & 26.43 & 27.06 & 26.08 & 26.33 \\
\hline $\begin{array}{l}\text { Saturation, } \\
(\%)\end{array}$ & - & 75.04 & - & 76.35 & - & 79.16 & - & 76.63 \\
\hline ITS, (kPa) & $1,327.7$ & 848.6 & $1,006.5$ & 705.2 & 1,159.1 & 679.9 & 759.2 & 563.9 \\
\hline TSR, $(\%)$ & & & 70. & & 58. & & & \\
\hline
\end{tabular}

$1 *$ Control group
$2^{*}$ Conditioned group

From the test results in Table 5., it was found that asphalt concrete mixed with PMA type asphalt cement and lower limit aggregate had a $6.15 \%$ higher TSR than asphalt concrete mixed with PMA type aggregate material with upper limit aggregate.

Similarly, asphalt concrete which was a mix of AC 6070 asphalt cement and lower limit aggregate materials had a $15.62 \%$ higher tensile strength than asphalt concrete comprising a mix of asphalt cement and upper limit aggregate materials.

Other research [32] tested asphalt concrete obtained by mixing asphalt cement and limestone using a controlled 
group that was similar to that in the current research. However, the additional $3^{*}$ set was the conditioned specimens that were not in the simulated environment by lowering the temperature to $-15{ }^{\circ} \mathrm{C}$ and those results are shown in Table 6. From this research, it was found that reducing the temperature of the asphalt concrete samples contributed to the TSR being reduced substantially. None of the mixtures in this research met the criteria for tensile strength for which the TSR value must be above $80 \%$ [33, 34].

Table 6 shows that the asphalt concrete mixed with PMA-type asphalt cement and the lower limit aggregate materials had a $10.14 \%$ higher TSR than the asphalt concrete mixed with the PMA-type aggregate material. Similarly, the asphalt concrete that was a combination of the asphalt cement type AC 60-70 and the lower limit aggregate materials had a $31.34 \%$ higher tensile strength than the asphalt concrete consisting of a combination of the asphalt cement type AC 60-70 and the upper limit aggregate materials.

In the ITS test, the asphalt concrete mixed with the asphalt cement type PMA had a higher ITS than the asphalt concrete mixed with the asphalt cement type AC 60-70. Considering moisture damage, the asphalt concrete mixed with the lower limit aggregate materials had a higher TSR than the asphalt concrete mixed with the upper limit aggregate materials.

Comparing the TSR with $5 \%$ air voids content (Table 5 ) with the $7 \%$ air void content (Table 6 ), there was a $16.03 \%$ reduction for the PMA UPPER asphalt concrete, a $12.04 \%$ reduction for the PMA LOWER, while the AC 60-70 UPPER decreased by $25.82 \%$ and the AC 60-70 LOWER decreased by $10.10 \%$.

The results for the asphalt concrete mixed with the aggregate material to the upper limit indicated that the PMA UPPER asphalt concrete had a higher TSR (\%) than the AC 60-70 UPPER asphalt concrete for both sets of air void volumes. For the $5 \%$ air void volume, the tensile strength of the PMA UPPER in the conditioned group was $24.82 \%$ greater than for the AC 60-70 UPPER and $7 \%$ greater for the tensile strength of the PMA UPPER. The conditioned group had $48.66 \%$ greater tensile strength than the AC 60-70 UPPER.

The PMA LOWER asphalt concrete had a TSR (\%) less than that of the AC 60-70 LOWER asphalt concrete for both sets of air void volumes. The $5 \%$ air void volume for the PMA LOWER in the conditioned group had $25.07 \%$ greater tensile strength than the AC 60-70 LOWER. For the $7 \%$ air voids, the PMA LOWER in the conditioned group had $15.84 \%$ greater tensile strength than the AC 60-70 LOWER.

TSR was defined as the ratio of ITS between the conditioned group and the control group to consider and compare the results of change in tensile strength obtained from the study as shown in Tables 5 and, 6. For the samples in the conditioned group, the environmental simulation test for freezing temperature meant that the water that displaced the air voids was frozen and expanded since water freezes. This could result in the force of the expansion being transferred to the structure and affect the adhesion between the aggregate and asphalt cement. Samples in the control group did not show this phenomenon. Thus, the tensile strength ratio of the conditioned group was less than 100\% in all cases.

\section{Conclusions}

The study showed that the resistance to moisture damage based on comparisons of the TSR method of asphalt concrete was dependent on the mixed size of the aggregate materials, with the samples composed of mixed sizes at the lower limit having a higher TSR than the mixed sizes at the upper limit.

The asphalt cement content had a direct effect on the TSR. The lower limit mixed aggregates had a higher content of asphalt cement in the mixture and therefore the moisture damage was higher than for the upper limit mixed aggregates.

The resistance to moisture damage was inversely proportional to the TSR; consequently, as the amount of air voids increased, the TSR decreased.

Based on these simulations of field behavior in Thailand, the appropriate type of asphalt cement should be considered carefully for differing areas where the asphalt concrete road surface is to be constructed to avoid water damage. There should be further research on performance grade asphalt cement that is suitable for the land features of Thailand to achieve road surfaces that are more resistant to moisture damage and have better engineering performance.

Table 6. Results of TSR test at $7 \%$ air voids.

\begin{tabular}{|c|c|c|c|c|c|c|c|c|c|c|c|c|}
\hline \multirow{2}{*}{$\begin{array}{l}\text { Type } \\
\text { Group }\end{array}$} & \multicolumn{2}{|c|}{ PMA UPPER } & \multicolumn{2}{|c|}{ PMA LOWER } & \multicolumn{4}{|c|}{ AC 60/70 UPPER AC 60-70 LOWER } & \multicolumn{2}{|c|}{ PMA [32] } & \multicolumn{2}{|c|}{ AC $60-70[32]$} \\
\hline & $1 *$ & $2^{*}$ & $1 *$ & $2 *$ & $1 *$ & $2^{*}$ & $1 *$ & $2^{*}$ & $1 *$ & $3 *$ & $1 *$ & $3 *$ \\
\hline Air voids, $(\%)$ & 6.98 & 7.19 & 6.78 & 7.06 & 7.10 & 7.15 & 6.54 & 6.61 & 6.84 & 6.75 & 7.02 & 6.92 \\
\hline Volume air voids, $\left(\mathrm{cm}^{3}\right)$ & 37.37 & 38.55 & 36.24 & 37.85 & 37.98 & 38.36 & 34.84 & 35.27 & 36.39 & 35.86 & 37.10 & 36.49 \\
\hline Saturation, $(\%)$ & - & 76.54 & - & 72.13 & - & 78.64 & - & 73.62 & - & 74.83 & - & 74.22 \\
\hline ITS, $(\mathrm{kPa})$ & 992.6 & 475.3 & 917.5 & 532.4 & 973.9 & 319.7 & 716.2 & 459.6 & 824.0 & 677.8 & 585.3 & 494.1 \\
\hline TSR, (\%) & \multicolumn{2}{|c|}{47.89} & \multicolumn{2}{|c|}{58.03} & \multicolumn{2}{|c|}{32.83} & \multicolumn{2}{|c|}{64.17} & \multicolumn{2}{|c|}{82.26} & \multicolumn{2}{|c|}{84.41} \\
\hline
\end{tabular}

$1 *$ Control group

2* Conditioned group

3* Conditioned group [32] 


\section{Acknowledgement}

The authors received financial assistance from the Faculty of Engineering at Kamphaeng Saen, Kasetsart University, Nakhon Pathom, Thailand.

\section{References}

[1] Ministry of Transport, Thailand, Information Technology and Communication Center, Office of The Permanent Secretary, "Length of road network in Thailand by category of road," 2020 .

[2] Wikipedia. "Generation Y." Wikipedia.org. http://en.wikipedia.org/wiki/Geography_of_Thail and (accessed Jul. 3, 2020).

[3] Climatological Center, Meteorological Department, Thailand, "The lowest temperature statistics during the winter in Thailand the period 69 years, $1951-$ 2019." $\quad$ Tmd.go.th. http://climate.tmd.go.th (accessed: Jul. 29, 2021).

[4] Climatological Center, Meteorological Department, Thailand, "The highest temperature statistics during the winter in Thailand the period 69 years, $1951-$ 2019." $\quad$ Tmd.go.th. http://climate.tmd.go.th (accessed: Jul. 29, 2021).

[5] S. Caro, E. Masad, A. Bhasin, and D. Little, "Moisture susceptibility of asphalt mixtures, Part I: Mechanisms," Int. J. Pavement Eng., vol. 9, no. 2, pp. 81-98, 2008.

[6] P. E. Sebaaly, E. Hitti, and D. Weitzel, "Effectiveness of lime in hot-mix asphalt pavements," Transportation Research Record: Journal of the Transportation Research Board, vol. 1832, pp. 34-41, 2003.

[7] I. M. A.Abuawad, I. L. Al-Qadi, and J. S. Trepanier, "Mitigation of moisture damage in asphalt concrete: Testing techniques and additives/modifiers effectiveness," Constr. Build. Mater., vol. 84, pp. 437443, 2015.

[8] A. Bhasin, D. N. Little, K. L. Vasconcelos, and E. Masad, "Surface free energy to identify moisture sensitivity of materials for asphalt mixes," Transportation Research Record: Journal of the Transportation Research Board, vol. 2001, pp. 37-45, 2007.

[9] J. Huang, S. Wu, L. Ma, and Z. Liu, "Material selection and design for moisture damage of HMA pavement," Mater. Sci. Forum., vol. 614, pp. 269-274, 2009.

[10] M. R. Kakar, M. O. Hamzah, and J. Valentin, “A review on moisture damages of hot and warm mix asphalt and related investigations," J. Clean. Prod., vol. 99, pp. 39-58, 2015.

[11] Y. Sun, S. Wua, Q. Liu, B. Li, H. Fang, and Q. Ye, "The healing properties of asphalt mixtures suffered moisture damage," Constr. Build. Mater., vol. 127, pp. 418-424, 2016.

[12] S. Cui, B. R. K. Blackman, A. J. Kinloch, and A. C. Taylor, "Durability of asphalt mixtures: Effect of aggregate type and adhesion promoters," Int J Adhes Adhes., vol. 54, pp. 100-111, 2014.

[13] A. Pasandín and I. Pérez, "The influence of the mineral filler on the adhesion between aggregates and bitumen," Int J Adhes Adhes., vol. 58, pp. 53-58, 2015.

[14] A. Khodaii, V. Khalifeh, M. H. Dehnad, and G. H. Hamedi, "Evaluating the effect of zycosoil on moisture damage of hot-mix asphalt using the surface energy method," J. Mater. Civ. Eng.., vol. 26, no. 2, pp. 259-266, 2014.

[15] N. M. Wasiuddin, C. M. Fogle, M. M. Zaman, and E. A. O'Rear, "Effect of anti-strip additives on surface free energy characteristics of asphalt binders for moisture-induced damage potential," J. Test. Eval., vol. 35, no. 1, pp. 36-44, 2007.

[16] T. M. Breakah, J. P. Bausano, and R. C. Williams, "Integration of moisture sensitivity testing with gyratory mix design and mechanistic-empirical pavement design," J. Transp. Eng., vol. 135, no. 11, pp. 852-857, 2009.

[17] R. B. Mallick, R. Pelland, and F. Hugo, "Use of accelerated loading equipment for determination of long term moisture susceptibility of hot mix asphalt," Int. J. Pavement Eng., vol. 6, no. 2, pp. 125-136, 2005.

[18] H. Peiwen and L. HongYing, "A laboratory study of the effectiveness of various additives on moisture susceptibility of asphalt mixtures," J. Test. Eval., vol. 34, no. 4P, pp. 261-268, 2006.

[19] C. Chen, A. A. Tayebali, and D. R. U. Knappe, "A procedure to quantify organic anti-strip additive in asphalt binders and mixes," J. Test. Eval., vol. 34, no. 4, pp. 269-274, 2006.

[20] R. A. Tarefder and M. Ahmad, "Evaluating the relationship between permeability and moisture damage of asphalt concrete pavements," J. Mater. Civ. Eng., vol. 27, no. 5, p. 04014172-10, 2014.

[21] E. A. Mercado, "Influence of fundamental material properties and air void structure on moisture damage of asphalt mixes," doctoral dissertation, Civil Enineering, Texas A\&M University, Texas, USA, 2007.

[22] O. N. Celik, "Air permeability of asphalt concrete made with shredded-tire rubber-modified binders and its relationship with porosity," J. Test. Eval., vol. 33, no. 4, pp. 217-222, 2005.

[23] S. Caro, E. Masad, A. Bhasin, and D. N. Little, "Moisture susceptibility of asphalt mixtures, Part 2: Characterization and modeling," Int. J. Pavement Eng., vol. 9, no. 2, pp. 99-114, 2008.

[24] B. Birgisson, R. Roque, G. C. Page, and J. Wang, "Development of new moistureconditioning procedure for hot-mix asphalt," Transp. Res. Rec.: Journal of the Transportation Research Board, vol. 2001, no. 1, pp. 46-55, 2007.

[25] B. Choubane, G. C. Page, and J. A. Musselman, "Effects of water saturation level on resistance of compacted hot-mix asphalt samples to moistureinduced damage," Transp. Res. Rec.: Journal of the 
Transportation Research Board, vol. 1723, pp. 97-106, 2000.

[26] G. Sugiyanto, "Characterization of asphalt concrete produced from scrapped tire rubber," Eng. J., vol. 21, no. 4, pp. 193-206, 2017.

[27] M. A. G. El-Sayed, " Effect of changing theoretical maximum specific gravity on asphalt mixture design," Eng. J., vol. 16, no. 4, pp. 137-148, 2012.

[28] P. Kasikitwiwat and K. Jantarachot, "Comparative study of fatigue of asphalt concrete mixed with AC 60-70 and polymer modified asphalt binder," Science \& Technology Asia., vol. 26, no. 3, pp. 39-49, 2021.

[29] K. Jantarachot, "The comparative study of asphalt concrete engineering properties between top limit and low limit criteria of aggregate mixed with asphalt cement AC 60-70 and PMA," KU Engineering Journal, vol. 95, pp. 11-22, 2016.

[30] F. Montanelli, "Fiber/Polymeric compound for high modulus Polymer Modified Asphalt (PMA)," Procedia Soc Behav Sci., vol. 104, pp. 39-48, 2013.
[31] J. S. Chen, T. J. Wang, and C. T. Lee, "Evaluation of a highly-modified asphalt binder for field performance," Constr. Build. Mater., vol. 171, pp. 539$545,2018$.

[32] N. Anantachaiyapong, "Permanent deformation resistance properties of lab-made asphalt concrete mixtures using lime stone aggregates," M.S. thesis, Department of Civil Engineering, Kasetsart University, Bangkok, Thailand, 2009.

[33] N. Khosla, B. G. Birdsall, and S. Kawaguchi, "Evaluation of moisture susceptibility of asphalt mixtures: Conventional and new methods," Transp. Res. Rec.: Journal of the Transportation Research Board, vol. 1728, pp. 43-51, 2000.

[34] S. I.S arsam and A. H. Alwan, "Impact of moisture damage on rutting resistance, shear and tensile properties of asphalt pavement," Int. J. Sci. Res., vol. 2, no. 10, pp. 453-462, 2014.

Panatda Kasikitwiwat was born in Bangkok, Thailand in 1972. She received her B.Eng in Civil Engineering from King Mongkut's Institute of Technology Ladkrabang in 1995, M.S. in Civil and Environmental Engineering (Transportation Engineering) from Northeastern University, USA in 1999 and Ph.D. degree in Civil and Environmental Engineering (Transportation Engineering) from Utah State University, USA in 2005.

She has been a faculty member at Kasetsart University on the Kamphaengsaen campus since 1997. Since 2013, she has been a Director of the Center of Excellence in Logistics at Kasetsart University. Dr. Panatda was a research coordinator for the Thailand Research Fund for Logistics and Supply Chain research area 2014-2016. Her research interests include performance measures for transportation network, logistics and supply chain, and highway improvement.

Siranya Thongchart was born in Yala Thailand in 1978. She received her B.Eng in Civil Engineering, M.Eng in Civil Engineering and D.Eng in Civil Engineering from Rangsit University in 2000, 2003 and 2008, respectively.

She has been a faculty members at Kasetsart University on the Kamphaengsaen Campus since 2008. Her research interests include soil mechanics, foundation design, uncertainty in parameters and soil materials.

Somchai Prayongphan was born in Bangkok Thailand in 1968. He received his B.Eng in Irrigation Engineering and his M.Eng in Civil Engineering from Kasersart University in 1990 and 1997, respectively, and his D.Eng in Civil Engineering from Nagoya University Japan in 2005.

He has been a faculty member at Kasetsart University on the Kamphaengsaen Campus since 2005. His research interest was include soil mechanics, soil improvement, earth slope stabilization and road structure design.

Krissana Jantarachot was born in Pattalung, Thailand in 1983. He received his B.Eng in Civil Engineering from Kasetsart University in 2005 and his M.S. in Civil Engineering (Transportation Engineering) from Kasetsart University in 2008.

He has been a faculty member at Kasetsart University on the Kamphaengsaen campus since 2009. His research interests include performance measures for highway materials. 